DOI: $10.25140 / 2411-5363-2021-3(25)-105-109$

UDC 621.865 .8

\author{
Rudolf Jánoš ${ }^{1}$, Denys Fetko ${ }^{2}$ \\ ${ }^{1}$ Associate Professor, Department of Production Systems and Robotics \\ Faculty of Mechanical Engineering, Technical University of Kosice (Kosice, Slovakia) \\ E-mail: rudolf.janos@tuke.sk. ORCID: http://orcid.org/0000-0002-5754-9278 \\ ${ }^{2}$ Student of Engineering Studies, Department of Production Systems and Robotics \\ Faculty of Mechanical Engineering, Technical University of Kosice (Kosice, Slovakia) \\ E-mail: Denys.fetko@student.tuke.sk
}

\title{
THE PNEUMOBIL DESIGN
}

The article describes the design of the body of a pneumobil that is to take part in international races. The shape of the body is designed in CAD software with emphasis on aerodynamic properties. There were also limitations in the design of the shape resulting from the safety and technological possibilities of production. The skeleton will be made of epoxy resin and glass fiber, which will be applied to the hoof made of extruded polystyrene by milling. The article describes the method of production, including technological conditions.

Keywords: pneumobil; compressed air; body; vehicle; composite material.

Fig.: 4. Table: 1. References: 7.

Urgency of the research. Given that there are significant climate changes at the moment and that they deal with a lot of topics, they are emissions and ecology, a large part of emissions are generated by motor vehicles. That is why in recent years manufacturers have been looking for an alternative. These include, for example, electric cars, hybrid drives, ethanol engines, hydrogen vehicles, as diesel vehicles are banned from entering in some cities. The experimental drive is a compressed air motor [3].

Target setting. The article is focused to the design of a pneumobil, which is prepared by our faculty and participated in the 2019 race. The pneumobil has a typical frame, but the body is worse in aerodynamics, exterior and weight. In the chapter they will be able to compare other vehicles that participate in the race. Modeling possibilities in CAD / CAM systems will be described. The body design will work in the Creo Parametrics program [2].

Actual scientific researches and issues analysis. Ongoing sales and EU rules are forcing more and more new products in vehicle propulsion systems than in any other area. In terms of the environment, not only the search for a more efficient system, but also so-called renewable energy sources or green energy drives can be developed as an alternative to a conventional internal combustion engine [4].

Analysis of existing research and publications. Every year since 2008, the Hungarian city of Eger has hosted international races on vehicles powered by compressed air. The event is intended for students of technical universities. The competition has three disciplines: maximum range, sprint and slalom. Our university has been regularly participating in the competition since 2018. In 2018, it was the first to participate in a three-wheeled vehicle with a star engine, which was quite a problem, and therefore in 2019 they participated in a completely new fourwheeled vehicle $[1 ; 2]$.

Introduction. In the twelfth year of the competition, our university participated in a 4 wheeled vehicle to create the body, we first needed to model a 3D model. For modeling, we used the CAD system Creo Parametric. Since it is possible to see our body in 2019 in (Fig. 1), it was created from several parts, we decided that it would be better to create the body than one whole part.

(C) Jánoš R., Fetko D., 2021 
TECHNICAL SCIENCES AND TECHNOLOGIES

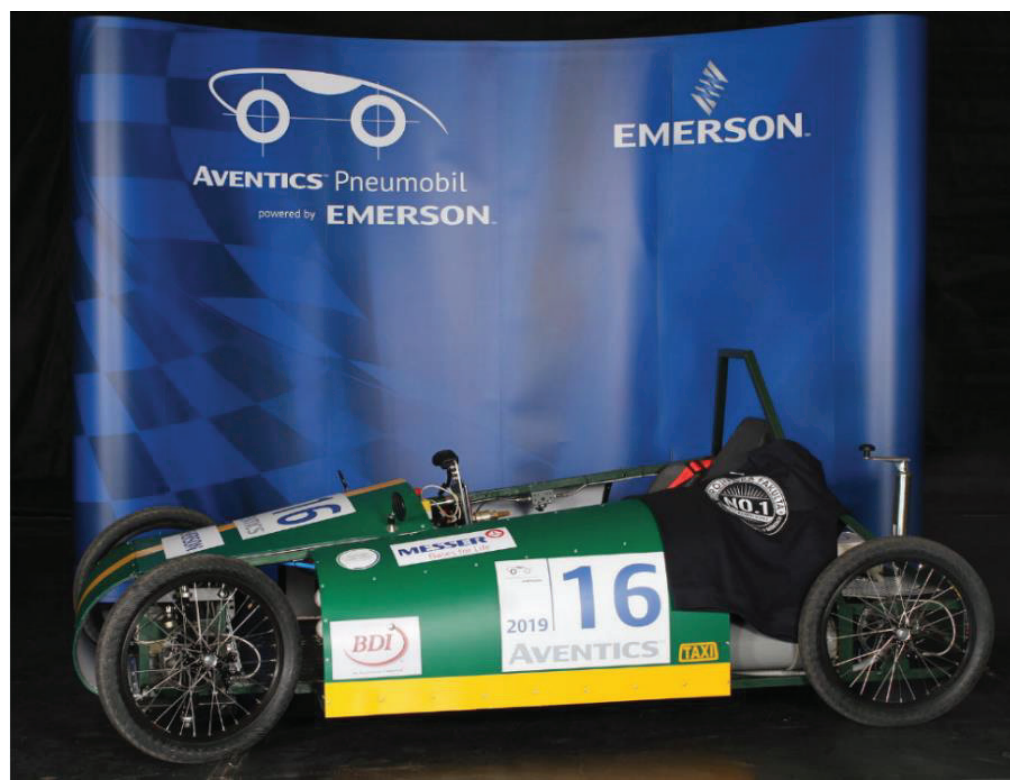

Fig. 1. Penumobil Air Force TUKE v 2019 [7]

The initial step in modeling in 3D CAD systems is to create a model of the part, followed by the creation of drawing documentation for this part. The software also enables the assembly of multiple parts into functional units, into so-called assemblies. It is again possible to create drawing documentation from the assembly. When creating a model in all 3D modeling software, including SolidWorks and Creo Parametric, the first step is to create a 2D or 3D sketch. This sketch can be placed on any plane or in space, in the case of a 3D sketch. After creating the sketch, the conversion of the area model into spatial comes. This allows a number of functions such as extruding a sketch into space, rotating around an axis, and so on. This step is stored with all parameters in the command tree, which clearly shows the construction process of the part. After analyzing the body of similar cars, our body will be built around the entire frame. The model was created according to the model of the frame, which had the exact dimensions of the car and the dimensions of the wheels, which in this case is important to us. The model has better aerodynamic properties, in the front part on both sides we have holes that are oriented for cooling the brakes and less air resistance. In (Fig. 2) is a front view of the body design. On (Fig. 3) it is possible to see the design of the body when viewed from behind [5].

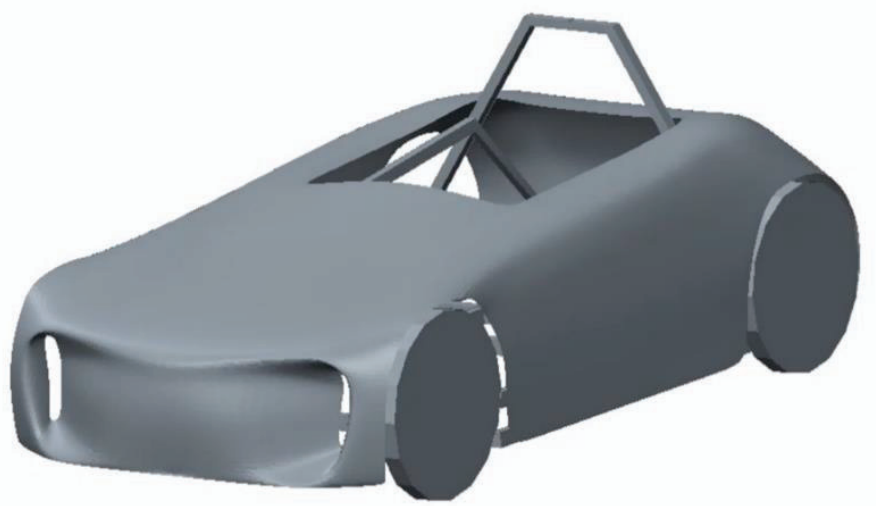

Fig. 2. Front of the body of pneumobil 


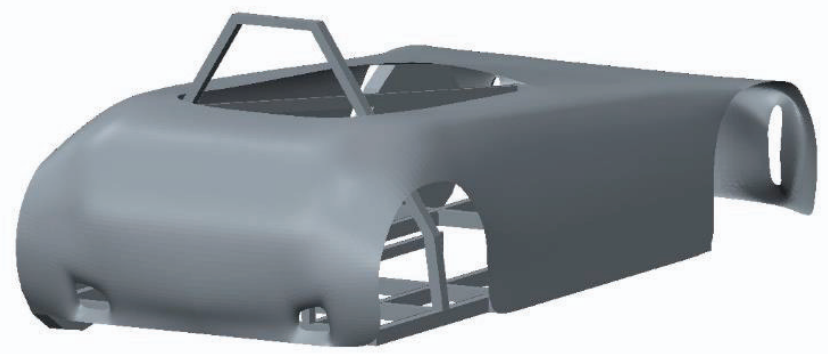

Fig. 3. Rear of the body of pneumobil

\section{Body production}

Design of the process of manufacturing the model of the body model using milling from polystyrene. Thanks to the created program, a real-size body model will be milled from extruded polystyrene, consisting of several parts that will be connected to each other and will form a realsize body model. Next, the process of producing the final version from epoxy resin and glass fiber will be described [4].

Table 1

General comparison of composite properties depending on the type of reinforcing fiber (+ Favorable, ++ very favorable, - unfavorable)

\begin{tabular}{|l|c|c|c|}
\hline \multirow{2}{*}{\multicolumn{1}{c|}{ Properties }} & \multicolumn{2}{c|}{ Composites } \\
\cline { 2 - 4 } & glass fibers & aramid composites & carbon composites \\
\hline Density & $+/-$ & ++ & + \\
\hline Tensile strength & + & + & + \\
\hline Flexibility & - & + & + \\
\hline Compressive strength & + & + & - \\
\hline Damping & - & + & ++ \\
\hline Static and dynamic stress & ++ & ++ & + \\
\hline Dielectric properties & ++ & + & - \\
\hline Adhesion properties & ++ & +- & + \\
\hline Price & ++ & & + \\
\hline
\end{tabular}

Using the program created in the CAM system from our 3D model, a body model, in real dimensions, will be milled on a CNC milling machine made of extruded polystyrene. Thanks to the possibilities of Creo, we can simulate the milling process and see the final product after milling, the process can be seen in (Fig. 4).
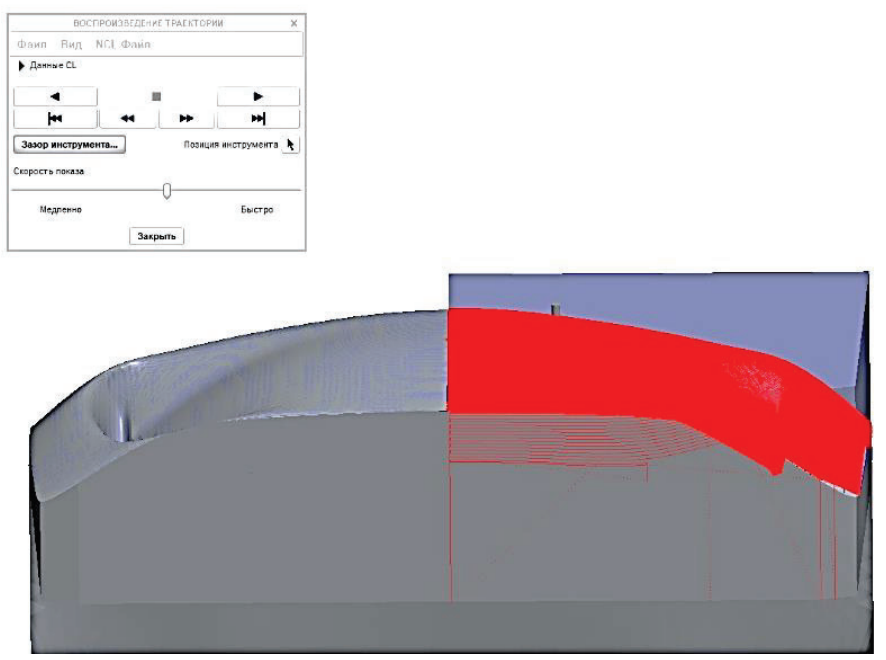

Fig. 4. Simulation of milling process 
In our case, the maximum dimension that can be milled is $1000 \times 500 \mathrm{~mm}$, because it is the maximum allowable size for our CNC machine. When milling, we use a $12 \mathrm{~mm}$ ball cutter for polystyrene. When milling, we divide the work into two stages. The first stage will involve rough machining (roughing), which has the task of removing as much material as possible in the shortest time, and we will enter the following parameters for the $\mathrm{CNC}$ machine:

spindle speed: $12000 \mathrm{rpm}$.

feed rate: $80 \mathrm{~mm} / \mathrm{s}$

immersion speed: $30 \mathrm{~mm} / \mathrm{s}$

The second stage consists of a welded phase of surface machining, the so-called finishing machining, in which the last remnants of material are removed and the part gets the final shape of the product. The following parameters are required for the operation:

spindle speed: $12000 \mathrm{rpm}$.

feed rate: $60 \mathrm{~mm} / \mathrm{s}$

immersion speed: $20 \mathrm{~mm} / \mathrm{s}$.

As a result, our model will consist of several parts that will need to be joined together. We will connect with the help of assembly foam and screws into one component as a whole, which will form a model of the body in real dimensions from polystyrene.

Subsequently, a flat surface without joints and unevenness will be created by machining. We will machine by grinding with corner thicknesses of sandpaper with a grain size from 60 to 400. And in the event of unevenness and gaps, we will apply putty.

The next step in production will be the preparation of a model for the application of polymeric material and reinforcing fiber. Firstly, it is necessary to ensure a better separation of the finished body from our model. Therefore, it is necessary to cover the model with aluminum tape, so that the composite material does not damage the polystyrene and apply a special separating wax to the surface. As a result, the model is then easily removed from the finished mold and will be undamaged.

We apply the composite material to the prepared model using a brush, in our case we chose an epoxy resin called thermoset. This material has many advantages, for example: easy production, low price, low weight and good properties under dynamic loading. After applying the first layer of epoxy resin, it is necessary to lay the reinforcing fiber with thin strips. As a reinforcing fiber, we chose glass fiber, which is also a better option for our body, due to its properties and especially the price. The fiber has relatively high strength and fire resistance. We apply epoxy resin to the deposited layer of glass fiber, the surface of it, 2-3 times, unless the thickness of our body is at least $1.5 \mathrm{~mm}$. After catching the material, we can separate our body from the model. After separation, we get the finished body as a whole made of composite material. For the final appearance of the body, it is necessary to prepare it for painting and create a flat surface, by grinding and guiding. The choice of sanding paper for machining depends on the evenness of the surface, for example, the grain size from G120 to G600. After reaching a flat surface, we can paint the body with synthetic paints.

Conclusions. The work is dedicated to the production of a car body, which is made by our university for participation in a car race in Hungary, in the city of Eger. Every year, races for compressed air cars have been held since 2008. Our university has been participating in the race since 2018. By designing a new body, we will improve the aerodynamic properties of the tire, which will improve our team's view of a better result. Based on the design, a body that will take part in the race next year will be produced, as we could not take part in the competition due to the COVID 19 pandemic.

Acknowledgements. This article was created thanks to the KEGA project support: 010TUKE-4/2020 Implementation of new knowledge and innovative approaches to the process of teaching robotics in line with Industry 4 and KEGA project support: 004TUKE-4/2021 Development of innovative teaching materials for learning multi-agent robotics. 


\title{
References
}

1. CHUNG, Deborah. Composite Materials: Science and Applications. 2. vyd. London: Springer, 2010, ISBN 9781848828308.

2. FREIBAUER, Martin, Hana VLÁČILOVÁ a Milena VILÍMKOVÁ. Základy práce v CAD systému SolidWorks. 2., aktualiz. vyd. Brno: Computer Press, 2010.

3. KRATOCHVÍL, Bohumil, Václav ŠVORČÍKa Dalibor VOJTĚCH. Úvod do studiamateriálů. Vyd. 1. Praha: Vysoká školachemicko-technologická, 2005.

4. PRAVEENGOUDA, P. Applications of Composites materials in the Automotive industry [online]. Last revision on 6th February 2010 http://www.scribd.com/doc/32475280/Composites-in-theAutomobile-Industry.

5. SADÍLEK, Marek. CAM systémy v obrábaní I. 1. vyd. Ostrava: VŠB -Technická univerzita Ostrava, 2008, 145 s. ISBN 978-80-248-1821-4.

6. SCHULTZ, R.M. Energyabsorption capacity of graphite-epoxy composite tubes [online]. Scholar.lib.vt.edu. Last revision on 20thNovember1998.

7. Pneumobil.hu. Exhibited pneumobiles [online]. www.pneumobil.hu (24.9.2021).

Отримано 25.06.2021

УДК 621.865 .8

\author{
Рудольф Янош', Денис Фетько ${ }^{2}$ \\ ${ }^{1}$ доцент, факультет машинобудування, кафедра виробничих систем та робототехніки \\ Технічний університет Кошице (Кошице, Словаччина) \\ E-mail: rudolf.janos@tuke.sk. ORCID: http://orcid.org/0000-0002-5754-9278

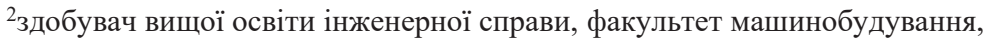 \\ кафедра виробничих систем та робототехніки \\ Технічний університет Кошице (Кошице, Словаччина) \\ E-mail: Denys.fetko@student.tuke.sk
}

\section{ДИЗАЙН ПНЕВМОБІЛУ}

Враховуючи, що на даний момент відбуваються значні зміни клімату і що вони стосуються багатьох тем, це викиди та екологія, значна частина викидів створюється автотранспортом. Ось чому останнім часом виробники шукають альтернативу. До них належать, наприклад, електромобілі, гібридні приводи, двигуни з етанолом, автомобілі з воднем, оскільки в деяких містах заборонено в "їзд автомобілям на дизельних двигунах. Експериментальний привід - ие двигун зі стисненим повітрям [3].

Стаття зосереджена на дизайні пневмомобіля, який підготовлений нашим факультетом та брав участь у перегонах 2019 року. Пневмомобіль має типову раму, але кузов гіриий за аеродинамікою, зовнішністю та вагою. У розділі вони зможуть порівняти інші транспортні засоби, які беруть участь у гониі. Буде описано можливості моделювання в системах CAD / CAM. Дизайн кузова праиюватиме в програмі Creо Parametrics. [2]

Поточні продажі та правила ЄС змушують стрворювати все більше нових продуктів у системах руху автомобілів, ніж у будь -якій іншій сфері. 3 погляду навколишнього середовища, не тільки пошук більш ефективної системи, але і так звані поновлювані джерела енергії або приводи зеленої енергії можуть бути розроблені як альтернатива звичайному двигуну внутрішнього згоряння [4].

Щороку, починаючи з 2008 року, угорське місто Егер проводить міжнародні гонки на автомобілях зі стисненим повітрям. Захід призначений для студентів технічних вузів. Змагання мають три дисиипліни: максимальну дистаниію, спринт та слалом. Наш університет регулярно бере участь у конкурсі з 2018 року. У 2018 рочі він першим взяв участь у триколісному транспортному засобі з двигуном зірки, щъо було досить проблематичним, і тому у 2019 роиі вони взяли участь у абсолютно новому чотириколісному а транспортному засобі [1; 2].

Робота присвячена виробництву кузова автомобіля, виготовленого нашим університетом для участі в автоперегонах в Угорщиині, в місті Егер. Щорічно гонки на автомобілях зі стисненим повітрям проводяться з 2008 року. Наш університет бере участь у перегонах з 2018 року. Розробивши новий кузов, ми покращимо аеродинамічні властивості шин, що покращить уявлення нашої команди про кращі результати. На основі дизайну буде виготовлено кузов, який візьме участь у перегонах наступного року, оскільки ми не могли взяти участь у конкурсі через пандемію COVID 19.

Ключові слова: пневмомобіль; стиснене повітря; кузов; транспортний засіб; композитний матеріал.

Рис.: 4. Табл.: 1. Бібл.: 7. 